\title{
Pergeseran Perilaku Sosial Laki-Laki Dalam Kegiatan Sosial
}

\author{
Rahmat Danil, Fatmariza, Junaidi Indrawadi \\ Program Studi Pendidikan Pancasila dan Kewarganegaraan \\ Universitas Negeri Padang \\ E-mail: danilrahmat996@gamil.com
}

\begin{abstract}
ABSTRAK
Penelitian ini bertujuan untuk mendeskripsikan pergeseran perilaku sosial laki-laki, faktor penyebab dan upaya meningkatkan kepedulian laki-laki dalam kegiatan sosial. Penelitian ini menggunakan pendekatan kualitatif yang dilakukan di Nagari Singgalang Kecamatan X Koto. Subyek penelitian adalah wali nagari, tokoh masyarakat, masyarakat lakilaki dewasa dan pemuda. Data dikumpulkan melalui wawancara, observasi dan dokumentasi, yang diuji keabsahanya melalui triangulasi terhadap sumber dan metode pengumpulan data. Hasil penelitian menunjukan adanya berbagai kegiatan sosial di Nagari Singgalang, seperti gotong royong, kegiatan keagamaan, keamanan dan lain-lain.
\end{abstract}

Kata Kunci: Pergeseran perilaku, Perilaku sosial, Kegiatan sosial

\section{ABSTRACT}

This research aims to describe changes in male social behavior, causal factors and efforts to increase men's awareness in social activities. This study uses a qualitative approach conducted in Nagari Singgalang Kecamatan X Koto. The research subjects were wali nagari, public figure, adult male and youth. Data was collected through interviews, observation and documentation, which tested its validity through source triangulation and method triangulation.

Keywords : Behavior shifts, Social behavior, Social activities

\section{PENDAHULUAN}

Dalam

kehidupan

bermasyarakat, perubahan sosial merupakan sesuatu yang lazim. Hal ini disebabkan karakter manusia sebagai makhluk yang dinamis dan terus berkembang. Perubahan sosial dalam masyarakat dapat berbentuk perubahan atas orientasi nilai, perilaku masyarakat, hingga sistem sosial masyarakat. Terjadinya perubahan sosial disebabkan oleh faktor-faktor yang berasal dari dalam maupun dari luar masyarakat tersebut. Perubahan sosial dapat berlangsung pada seluruh aspek kehidupan masyarakat atau terbatas pada aspek-aspek tertentu saja (Ahmadi, 2009).

Masyarakat Nagari Singgalang merupakan salah satu masyarakat yang mengalami perubahan dalam kehidupan sosialnya, terutama dalam hal perilaku sosial laki-laki di nagari tersebut. Sebagian besar penduduk di daerah tersebut terdiri dari etnis Minangkabau. Dalam khazanah budaya Minangkabau, laki-laki memiliki peran sebagaimana disebutkan dalam pepatah adat berikut: 
“Kaluak paku kacang balimbiang, tampuruang lengganglenggangkan, baok manurun ka Saruaso, tanam sirieh jo ureknyo.

Anak dipangku kamanakan dibimbiang, urang kampuang dipatenggangkan, tenggang nagari jan binaso, tenggang sarato jo adatnyo."

("relung paku kacang belimbing, tempurung dilenggang-lenggangkan, bawo menurun ke Saruaso, tanam sirih beserta akarnya.

Anak dipangku kemenakan dibimbing, orang kampung dipertenggangkan, tenggang nagari jangan sampai binasa, tenggang serta dengan adatnya.")

Pepatah adat tersebut menunjukan luasnya tugas seorang laki-laki menurut adat Minangkabau. Idealnya seorang laki-laki di Minangkabau tidak hanya berkewajiban mengurus rumah tangganya, namun juga membimbing kemenakannya dan pula menjaga hubungan dengan lingkungan sosialnya. Ketiga hal itu harus terlaksana secara adil dan tidak berat sebelah, demi menjaga kelestarian tatanan masyarakat (Latief, 2002). Dengan demikian dapat disimpulkan bahwa menurut nilai tradisional dalam masyarakat, seorang laki-laki harus berperilaku sebagai ayah bagi anaknya (biologis-ekonomis-edukatif), pembimbing bagi kemenakannya (sosiologis-edukatif), dan sebagai bagian dari masyarakatnya (sosiologis).

Kedudukan laki-laki sebagai anggota masyarakat tidak kalah pentingnya dengan kedudukannya sebagai seorang ayah ataupun sebagai seorang mamak. Sebagai bagian dari masyarakat, seorang laki-laki berkewajiban untuk ikut 'mempertenggangkan' dengan orang kampungnnya dan dengan pergaulan dalam nagari dan adatnya. Hal ini merupakan suatu nilai sosial yang berlaku sejak dahulu pada masyarakat Nagari Singgalang, mengacu dengan adanya berbagai kegiatan sosial yang ada beserta keikutsertaan masyarakat dalam kegiatan-kegiatan tersebut. Kegiatan sosial yang ada di Nagari Singgalang antara lain, gotong royong, kegiatan keagamaan, kegiatan sosial keamanan dan kegiatan melayat orang meninggal dan menjenguk orang sakit.

Adanya dorongan dari internal masyarakat maupun disebabkan pengaruh dari eksternal telah membawa perkembangan kehidupan masyarakat Nagari Singgalang. Perkembangan kehidupan masyarakat tersebut menyebabkan terjadinya berbagai perubahan dalam kehidupan masyarakat Nagari Singgalang. Hal ini juga berimbas pada perilaku sosial masyarakat dalam kegiatan sosial, terutama masyarakat laki-laki.

Sebelumnya telah ada berbagai penelitian yang menyinggung masalah perilaku laki-laki, akan tetapi sedikit yang membahas tentang pergeseran perilaku sosial laki-laki dalam kegaiatan sosial. Adapun penelitian ini fokus terhadap perubahan perilaku sosial laki-laki, dengan tujuan mendeskripsikan bentuk pergeseran perilaku sosial laki-laki, faktor penyebab dan upaya yang dilakukan untuk meningkatkan kepedulian sosial laki-laki di Nagari Singgalang Kecamatan $X$ Koto. Tujuan dari pembuatan artikel ini yaitu agar mendeskripsikan pergeseran perilaku sosial masyarakat laki-laki dan dampaknya terhadap kehidupan sosial, mengidentifikasi faktor 
penyebab terjadinya pergesran perilaku sosial di Nagari Singgalang Kecamatan $X$ koto, mengidentifikasi upaya yang dilakukan dalam peningkatan kepedulian masyarakat terhadap kegiatan sosial di Nagari Singgalang kecamatan $\mathrm{X}$ koto. Dan manfaat dari pembuatan artikel ini yaitu sebagai referensi untuk penelitian selanjutnya yang sejenis dan bahan masukan bagi pemerintah setempat dan contoh bagi kenagarian lain dalam rangka melakukan pengembangan dalam pemberdayaan laki-laki dan perempuan.

Dalam state of the art diambil beberapa contoh penelitian terdahulu sebagai pandun atau contoh untuk penelitian yang dilakukan yang anntinya akan menjadi acuan dan perbandingan dalam melakukan penelitian ini. Berikut penelitian terdahulu yang membahas tentang perubahan perilaku masyarakat:

1. Penelitian yang berjudul Perubahan perilaku masyarakat di lingkungan kawasan industri, peneliti bernama Eni Haryati pada tahun 2016. Pada penelitian ini ditemukan bahwa dalam perilaku bergotong royong pada bidang penanganan musibah, kepentingan umum, dan hajatan masyarakat sangat antusias untuk mengikuti kegiatan kerja bakti. Tetapi setelah hadir kawasan industri perilaku masyarakat dalam kegiatan gotomg royong mengalami perubahan. Yaitu perilaku masyarakat lebih berorientasi pada materi atau sistem upah serta lebih dominan memberi bantuan dalam bentuk finansial daripada bantuan tenaga.

2. Penelitian yang dilakukan Ayi Sentosa (2010), dengan judul
Gotong royong pada masyarakat perdesaan. hasil penelitian ini menunjukkan bahwa kegiatan gotong royong masih ada dan terpelihara kelesteraiannya dengan adanya kegiatan royong seperti jum'at bersih, pembersihan makam, gotong royong dalam dana untuk memeriahkan hari kemerdekaan indonesia dan sebagainya.

3. Penelitian yang dilakukan Febri Cahya Gumelar (2012) yang berjudul Dampak perubahan mata pencaharian perilaku masyarakat di pantai harapan jaya kabupaten bekasi, dengan menggunakan metode kualitatif. Hasil penelitian menunjukkan bahwa secara umum tidak mengalami perubahan yang signifikan yaitu masih berbau masyarakat desa. Sedangkan perilaku yang berkaitan dengan perilaku ekonomi, perilaku pola pikir dan perilaku gaya hidupnya, secara umum mengalami perubahan.

4. Penelitian yang dilakukan oleh Ana Rosita Sari (2006) yang berjudul Industrialisasi dan perubahan pola perilaku masyarakat desa. Hasil menunjukkan bahwa bahwa terjadi perubahan mata pencaharian ke sektor industrialisasi yang secara tidak langsung terjadi perubahan mata pencaharian kesektor industri. Sedangkan perilaku masyarakat tidak peduli pada lingkungan sekitarnya atau individualistik. Dan menyebabkan sifat kebersamaan masyarakat menjadi pudar.

\section{METODE PENELITIAN}

Penelitian ini menggunakan pendekatan kualitatif deskriptif untuk mendeskripsikan bentuk perubahan 
perilaku sosial laki-laki, faktor-faktor yang mempengaruhi dan upaya meningkatkan tanggung jawab sosial laki-laki. Informan dalam penelitian ini dipilih dengan metode purpossive sampling, yaitu pemilihan informan yang memahami dan menguasai masalah pergeseran perilaku sosial laki-laki. Adapun informan dalam penelitian ini adalah walinagari, perangkat nagari, tokoh masyarakat dan masyarakat Nagari Singgalang. Data dikumpulkan melalui wawancara, observasi dan studi dokumentasi yang dilakukan selama 6 bulan. Dalam mengumpulkan data, peneliti menggunakan pedoman wawancara dan pedoman observasi, serta dibantu dengan alat perekam, kamera dan buku catatan. Data yang dikumpulkan kemudian dianalisa dengan mereduksi atau memilih data yang benar-benar berkaitan dengan penelitan.Kemudian peneliti menyajikan data hasil penelitian dalam bentuk naratif yang dapat dipahami pembaca, selanjutnya peneliti melakukan verifikasi serta menarik kesimpulan dari hasil penelitian yang ditemukan.Untuk menguji keabsahan data hasil penelitian, peneliti menggunakan teknik triangulasi, yaitu pengecekan data melalu berbagai teknik, sumber dan metode yang digunakan. Peneliti menggunakan teknik triangulasi sumber untuk membandingkan informasi dari informan-informan penelitian yang telah di wawancara dan di amati peneliti selama di lapangan. Melalui triangulasi metode, peneliti membandingkan antara hasil observasi dengan hasil wawancara, membandingkan hasil observasi dengan dokumentasi serta juga membandingkan hasil wawancara dengan dokumentasi mengenai pergeseran perilaku sosial laki-laki di Nagari Singgalang

\section{HASIL DAN PEMBAHASAN}

\section{Pergeseran Perilaku Sosial Masyarakat Laki-Laki}

Masyarakat Nagari Singgalang sejak lama dikenal sebagai masyarakat yang memiliki antusiasme yang tinggi dalam berbagai kegiatan yang ada. Kegiatan-kegiatan tersebut antara lain, kegiatan gotong royong, kegiatan ronda malam, menjenguk atau melayat orang meninggal, dan kegiatan sosial di bidang agama masyarakat sangat antusias mengikutinya. Tingginya antusiasme masyarakat dalam kegiatan-kegiatan tersebut menunjukan kuatnya nilai kekeluargaan dan kebersamaan dalam masyarakat. Selain itu, tingginya antusiasme masyarakat juga didorong oleh pengaruh tokoh Angku Palo. Angku palo merupakan Wali Nagari Singgalang yang sangat berpengaruh pada kemajuan nagari singgalang. Pada era pemerintahan Angku Palo masyarakat sangat antusias mengikuti semua kegiatan yang direncanakan Nagari termasuk dalam kegiatan sosial. Karena Angku Palo adalah sosok yang sangat disegani di Nagari Singgalang.

Saat ini terjadi penurunan antusiasme masyarakat dalam kegiatan sosial, khususnya pada masyarakat laki-laki. Hal ini terlihat dari hasil observasi di lapangan, dalam beberapa kegiatan sosial yang dilaksanakan, hanya sedikit masyarakat laki-laki yang hadir. Rendahnya antusiasme laki-laki dalam kegiatan sosial tersebut dikarenakan kurangnya informasi dan prioritas utama terhadap pekerjaan dan 
kebutuhan rumah tangga masingmasing. Lebih lanjut, pergeseran perilaku sosial laki-laki dalam kegiatan sosial masyarakat Nagari Singgalang dapat dilihat dalam tabel berikut.

\section{Tabel 1. Pergeseran Perilaku Sosial}

Laki-Laki dalam Kegiatan Sosial Masyarakat Nagari Singgalang

\begin{tabular}{|c|c|c|}
\hline No & $\begin{array}{l}\text { Perilaku Sosial } \\
\text { Mayarakat Laki- } \\
\text { Laki Dulu }\end{array}$ & $\begin{array}{l}\text { Perilaku Sosial } \\
\text { Masyarakat Laki- } \\
\text { Laki Sekarang }\end{array}$ \\
\hline 1 & $\begin{array}{lr}\text { Dalam mengikuti } \\
\text { gotong royong } \\
\text { masyarakat antusias } \\
\text { dan ramai }\end{array}$ & $\begin{array}{lr}\text { Masyarakat } & \text { sibuk } \\
\text { dengan } & \text { urusan } \\
\text { pribadi, } & \text { sehingga } \\
\text { gotong royong tidak } \\
\text { ramai }\end{array}$ \\
\hline 2 & $\begin{array}{lr}\text { Kepala } & \text { jorong } \\
\text { dengan } & \text { ketua } \\
\text { pemuda } & \\
\text { menggerakan } & \\
\text { masyarakat untuk } \\
\text { berpartisipasi } \\
\text { dalam proses } \\
\text { pemakaman orang } \\
\text { meninggal dan } \\
\text { melihat orang sakit }\end{array}$ & 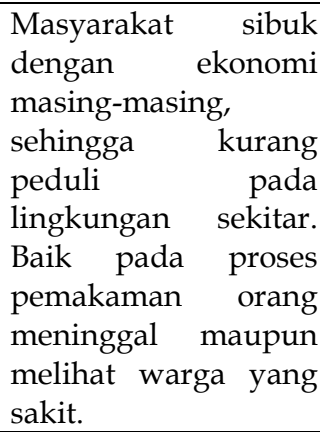 \\
\hline 3 & $\begin{array}{lr}\text { Dalam } & \text { kegiatan } \\
\text { ronda } & \text { malam } \\
\text { masyarakat } & \text { hadir } \\
\text { tanpa } & \text { unsur } \\
\text { paksaan, } & \text { melainkan } \\
\text { keinginan } & \text { mereka } \\
\text { sendiri } & \\
\end{array}$ & $\begin{array}{l}\text { Ronda malam sudah } \\
\text { tidak dilaksanakan } \\
\text { lagi karena sudah } \\
\text { mulai memudarnya } \\
\text { sikap kebersamaan }\end{array}$ \\
\hline 4 & $\begin{array}{lr}\text { Dalam mengikuti } \\
\text { kegiatan } \\
\text { dibidang } & \text { agamial } \\
\text { khususnya pada } \\
\text { kegiatan pengajian } \\
\text { masyarakat yang } \\
\text { hadir berimbang } \\
\text { antara laki-laki dan } \\
\text { perempuan }\end{array}$ & $\begin{array}{lr}\text { Tingkat } & \text { kehadiran } \\
\text { dalam kegiatan sosial } \\
\text { dibidang } & \text { agama } \\
\text { khususnya } & \text { pada } \\
\text { kegiatan pengajian } \\
\text { didominasi } & \text { oleh } \\
\text { kaum perempuan, } \\
\text { laki-laki banyak tidak } \\
\text { hadir r karena } \\
\text { beralasan } & \text { kecapekan, } \\
\text { malas } & \end{array}$ \\
\hline 5 & $\begin{array}{l}\text { Masyarakat banyak } \\
\text { bekerja sebagai } \\
\text { petani sehingga } \\
\text { lebih banyak waktu } \\
\text { untuk mengikuti } \\
\text { kegiatan sosial }\end{array}$ & $\begin{array}{l}\text { Masyarakat banyak } \\
\text { bekerja sebagai buruh } \\
\text { tani sehingga tidak } \\
\text { ada waktu untuk } \\
\text { mengikuti kegiatan } \\
\text { sosial }\end{array}$ \\
\hline
\end{tabular}

Berdasarkan tabel di atas, dapat diketahui tentang bentuk-bentuk pergeseran perilaku sosial laki-laki dalam kegiatan sosial masyarakat Nagari Singgalang. Pergeseran perilaku sosial tersebut antara lain kurangnya partisipasi masyarakat laki-laki dalam kegiatan gotong royong, kegiatan ronda malam, melayat orang meninggal atau menjenguk orang sakit, kegiatan keagamaan dan lain-lain.

Faktor yang Menyebabkan Rendahnya Kepedulian Sosial Laki-laki dalam Kegiatan Sosial di Nagari Singgalang

Pergeseran perilaku sosial lakilaki dalam kegiatan sosial di Nagari Singgalang disebakan oleh beberapa faktor, antara lain:

\section{a. Kecemburuan Sosial}

Terjadinya pergeseran perilaku masyarakat laki-laki dalam mengikuti kegiatan sosial dikarenakan komunikasi yang kurang harmonis antar perangkat desa dan terjadinya kecemburuan sosial yang belum diatasi secara kekeluargaan. Hal ini terlihat pada kegiatan sosial menjenguk orang sakit, dimana ketika ada masyarakat yang sakit tidak dibesuk oleh pemuda maka terjadi kecemburuan ditengah masyarakat yang mengatakan ketua pemuda dan anggota tidak adil dalam menjalankan perannya.

\section{b. Sikap Mementingkan Diri Sendiri}

Pergeseran perilaku sosial masyarakat laki-laki di Nagari Singgalang juga disebabkan pengaruh globalisasi yang membuat masyarakat hidup serba instan dan membuat masyarakat menjadi malas mangikuti kegiatan sosial. Salah satu alasan masyarakat tidak mengikuti kegiatan sosial adalah karena lebih 
memprioritaskan urusan keluarga mereka. Selain itu masyarakat di Singgalang juga cenderung berpikir pragmatis, dimana mereka hanya akan bekerja bila mendapatkan upah.

\section{Upaya Meningkatkan Kepedulian Sosial Laki-laki dalam Kegiatan Sosial di Nagari Singgalang}

Untuk meningkatkan kepedulian sosial laki-laki di Nagari Singgalang, berikut upaya-upaya yang telah dilakukan, yaitu:

\section{a. Upaya yang dilakukan Pemerintah Nagari}

Upaya yang $\quad \begin{array}{r}\text { dilakukan } \\ \text { pemerintah dalam }\end{array}$
meningkatkan partisipasi masyarakat
untuk mengikuti kegiatan sosial yaitu
dengan memberikan sanksi kepada
masyarakat yang tidak hadir. Selain
itu, agar masyarakat berpartisipasi
dalam kegiatan sosial dilakukan upaya
penyuluhan, himbauan, dan
mendekati tokoh masyarakat.

\section{b. Upaya yang dilakukan Kepala Jorong dan Tokoh Mayarakat}

Dalam meningkatkan partisipasi masyarakat untuk mengikuti kegiatan sosial, kepala jorong dan tokoh mayarakat melakukan upaya-upaya sebagai berikut. Pertama, mengundang tokoh-tokoh masayarakat dan masyarakat untuk bermusyawarah mengenai pelaksanaan kegiatan sosial, seperti menentukan hari yang bagus untuk gotong royong, mengumpulkan uang sosial dan sebagainya. Kemudian upaya lain adalah dengan mengajak atau menjemput masyarakat dari rumah masing-masing. Selain itu dalam meningkatkan partisipasi masyarakat untuk mengikuti kegiatan sosial yaitu dengan memberikan himbauan dan pengumuman. Dalam meningkatkan partisipasi masyarakat untuk mengikuti kegiatan sosial yaitu para Niniak Mamak di Nagari Singgalang menegur secara langsung keluarga mereka atau anak kemenakan yang malas untuk mengikuti kegiatan sosial.

\section{Pergeseran Perilaku Sosial Masyarakat Laki-Laki}

Berdasarkan hasil penelitian di atas, dapat dilihat pergeseran perilaku sosial pada masyarakat laki-laki pada masa dahulu dan masa sekarang. Saat ini keikutsertaan masyarakat dalam kegiatan sosial mengalami penurunan dan ikatan kolektivitas (kebersamaan) memudar secara perlahan. Padahal sebagai masyarakat yang tinggal di kawasan pedesaan, seharusnya mereka masih memegang nilai-nilai tradisional yaitu memiliki ikatan perasaan yang erat dan orientasi yang bersifat kebersamaan (kolektivitas) yang kuat Jamaludin (2015:305). Pergeseran perilaku masyarakat dalam kehidupan sosial karena masyarakat lebih bersifat konsumtif dan matreailistik, dimensi-dimensi hubungan sosial dan gaya hidup di perdesaan mulai berubah dan menyesuaikan diri dengan kehidupan modern sesuai kemampuan akses yang dimiliki. Menurut Durkheim (dalam Beihardz,2005) mengungkapakan, perubahan yang terjadi karena modernitas secara lambat laun menggeser pola kehidupan sosial masyarakat secara perlahan, pembagian kerja karena proses industrialisasi, pencerahan dan individualism telah bergeser nilai-nilai sosial masyarakat khususnya nilainilai tradisional masyarakat. 


\section{Faktor Penyebab Terjadinya Pergeseran Perilaku Sosial}

Pergeseran perilaku masyarakat dapat terjadi karena adanya pertentangan yang terjadi baik dalam bentuk perorangan maupun dalam kelompok. Dalam kehidupan masyarakat awal timbulnya pertentangan karena kecemburuaan sosial, ada sebagaian kelompok tertentu yang tidak suka dengan gaya kepemimpinan seseorang dan kelompok tersebut membuat kerusuhan agar masyarakat terpecah belah. Sesuai dengan pendapat Setiadi dan Kolip (2011) yang mengatakan faktor yang menyebabkan konflik sosial yaitu perbedaan pendirian dan keyakinan orang perorangan maupun kelompok serta terjadinya konflik karena kemajemukan vertikal yang artinya struktur masyarakat berdasarkan kekayaan, pendidikan dan kekuasaan.

Selain konflik yang disebabkan oleh kecemburuan sosial, faktor lainnya adalah perubahan nilai dalam masyarakat. Menurut Soerjono Soekanto (dalam Jamaludin, 2015:79), perubahan sosial merupakan gejala berubahnya struktur sosial dan pola budaya dalam suatu masyarakat, seperti nilai-nilai dan norma sosial, pola prilaku, susunan lembaga, interaksi sosial dan lain-lain. Dalam hal ini, pergeseran perilaku sosial lailaki di Nagari Singgalang disebabkan oleh perubahan orientasi nilai kebersamaan menjadi nilai-nilai individualistik.

\section{Upaya Meningkatkan Kepedulian Sosial Laki-laki dalam Kegiatan Sosial di Nagari Singgalang}

Dalam meningkatkan pertisipasi masyarakat terhadap kegiatan sosial harus ada komunikasi yang baik antar perangkat nagari dengan kepala jorong, kepala jorong dengan masyarakat. Setiap ada suatu pengambilan keputusan harus melibatkan semua komponen dalam Nagari tersebut. Partisipasi tidang datang dengan sendirinya, dibutuhkan usaha-usaha untuk menumbuhkan semangat masyarakat. Salah satu segi yang perlu mendapatkan perhatian yaitu komunikasi, hal ini sesuai dengan pendapat Bintoro Tjokoroamidjojo (1986) yang mengatakan gagasan-gagasan, kebijakasanaan, dan rencana hanya akan mendapatkan dukungan apabila diketahui kemudia dimengerti. Komunikasi merupakan suatu hal yang sangat penting, aspirasi dan kepentingan berbagai kelompok masyarakat dan pengembangan terhadap tujuan-tujuan yang bersifat pembanguanan harus ada komunikasi yang baik. Berdasarkan hasil temuan peneliti dilapangan dalam meningkatkan kepedulian masyarakat terhadap kegiatan sosial sudah dilakukan komunikasi yang baik antar perangkat nagari. Sudah adanya pengambilan keputusan melalui musyawarah, sudah adanya komunikasi yang baik antar perangkat nagari.

\section{KESIMPULAN}

Pergeseran perilaku sosial masyarakat laki-laki di Kenagarian Singgalang dapat dilihat dari bagaimana pergeseran itu sendiri dan dampaknya terhadap kehidupan sosial. Masyarakat yang mayoritas bekerja sebagai petani sulit membagi 
waktu antara bekerja atau ikut dalam kegiaran sosial. Pergeseran perilaku sosial masyarakat dapat dilihat dari perilaku masyarakat dahulu dan yang terjadi saat sekarang ini. Faktor penyebab terjadinya pergeseran perilaku sosial di Nagari Singgalang yaitu terjadinya kecemburuan sosial ditengah-tengah masyarakat.

Kecemburuan sosial ini terjadi karena timbulnya perbedaan pendapat antar masyarakat. Selain itu sifat mementingkan diri sendiri yang terjadi pada masyarakat juga menjadi salah satu faktor penyebab terjadinya pergeseran perilaku sosial. Upaya yang dilakukan pihak Nagari, kepala jorong, tokoh masyarakat, dan pemuda dalam meningkatkan partisipasi masyarakat untuk mengikuti kegiatan sosial adalah dengan cara pemberian sanksi, memberikan himbauan atau pengumuman, teguran, dan musyawarah belum berdampak signifikan.

Berdasarkan penjelasan tersebut penulis menyarankan bahwa Wali Nagari Singgalang harus terus memberikan penyuluhan atau informasi terkait dengan kegunaan dari kegiatan sosial. Kegiatan sosial harus dilakukan di hari yang tidak mengganggu pekerjaan masyarakat untuk mendongkrak kehadiran masyarakat. Selain itu masyarakat di Nagari Singgalang harus sadar akan kegunaan dari kegiatan sosial itu sendiri serta mampu mengatur prioritas antara bekerja dan bersosialisasi dengan masyarakat lainnya

\section{DAFTAR PUSTAKA}

Jamaludin, Adon Nasrulla. (2015). Sosiologi Perdesaan. Bandung: CV Pustaka Setia.

Rahardjo. (2010). Sosiologi Perdesaan dan Pertanian, Gajah Mada University Press, Yogyakarta.

Setiadi, Elly M. dan Usman Kolip. (2011). Pengantar Sosiologi Pemahaman Fakta dan Gejala Permasalahan Sosial: Teori, Aplikasi dan Pemecahannya. Jakarta: Kencana Prenada Media Group.

Soekanto, Soerjono. (2012). Sosiologi Suatu Pengantar. Jakarta: Rajawali Press 